\title{
STRATEGI MADRASAH IBTIDAIYAH DALAM MENINGKATKAN PROFESIONALISME GURU KELAS DI ERA REVOLUSI INDUSTRI 4.0
}

\author{
Bela Vita Rismawati ${ }^{1}$, Muhamad Arif², Muhammad Mahfud ${ }^{3}$ \\ ${ }_{123}^{12}$ TAI Al-Azhar Menganti Gresik \\ e-mail: 1리avita5@gmail.com, ${ }^{2}$ muhamadarif070593@gmail.com, \\ 3mahfudmuhammad2020@gmail.com
}

Diterima: 15 Maret 2021 I Direvisi: 26 Mei 2021 I Disetujui: 30 Mei 2021 (C) 2021

Pendidikan Guru Madrasah Ibtidaiyah Fakultas Agama Islam Universitas Islam Malang

\begin{abstract}
Abstrak
Profesionalisme bagi guru Sekolah Dasar/Madrasah Ibtidaiyah adalah sebuah keniscayaan yang harus dimiliki, pemaparan profesionalisme bagi guru terdapat empat kompetensi minimal yaitu pedagogik, profesional, sosial dan kepribadian. Pada dasarnya pembahasan tentang profesionalisme guru sebenarnya sudah teratur sangat jelas pada "Permendiknas Nomor 16 Tahun 2007 tentang Standar Kualifikasi Akademik dan Kompetensi Guru. Namun, dunia pendidikan mendapatkan tantangan yang cukup berat, ketika memasuki era revolusi industry 4.0. posisi guru menjadi posisi kunci dalam mengawal keberhasilan pembelajaran di tengah arus digitalisasi. Maka, satu-satunya yang dapat dilakukan adalah secara continue meningkatkan kompetensi yang dimilikinya. Riset ini mencari jawab dari strategi madrasah ibtidaiyah Miftahul Ulum Kesamben Wetan dalam meningkatkan profesionalisme di era revolusi industry 4.0. penelitian ini menggunakan metode kualitatif studi kasus dengan teknik pengumpulan data melalui wawancara, observasi dan dokumentasi, serta didukung analisis data dari miles dan huberman. Hasil penelitian menunjukkan bahwa Strategi madrasah ibtidaiyah Miftahul Ulum Kesamben Wetan Driyorejo Gresik, dalam meningkatkan profesionalisme guru di era revolusi 4.0 meliputi: (1) Pelatihan berbasis IT, (2) Seminar Pendidikan, (3) Workshop pembelajaran di era revolusi industri 4.0, (4) Lokarya pendidikan dan pembelajaran di era digital, (5) Supervisi Madrasah yang dilakukan oleh kepala madrasah ibtidaiyah, (6) Bimtek yang di adakan oleh madrasah, (7) Mendorong dan memotivasi para guru untuk mengikuti Kelompok Kerja Guru (KKG), (8) Mengadakan Studi Banding kepada lembaga yang lebih bermutu, (9) Mengadakan bakti sosial kepada sekitar madrasah dan masyarkat yang membutuhkan. (10) Sarasehan bersama kyai sekitar untuk menguatkan perjuangan, (11) Ngaji Bareng kerja sama antara Madrasah Ibtidaiyah dan LP Maarif NU Driyorejo.
\end{abstract}

Kata kunci: Profesionalisme, Guru, Revolusi Industri 4.0.

\begin{abstract}
Professionalism for Elementary School / Madrasah Ibtidaiyah teachers is a necessity that must be possessed, in the presentation of professionalism for teachers there are four minimum competencies, namely pedagogic, professional, social and personality. Basically, the discussion about teacher professionalism is actually very clear in the "Minister of Education Regulation No. 16 of 2007 on Academic Qualification Standards and Teacher Competencies. However, the world of education faces quite a tough challenge, when it enters the era of the industrial revolution 4.0. the position of the teacher is a key position in guarding the success of learning in the midst of digitalization. So, the only thing that can be done is to continuously improve its competence. This research seeks answers from
\end{abstract}


the strategy of the Miftahul Ulum Kesamben Wetan Islamic school in increasing professionalism in the era of the industrial revolution 4.0. This research uses a qualitative case study method with data collection techniques through interviews, observation and documentation, and is supported by data analysis from miles and hubarman. The results showed that the strategy of Madrasah ibtidaiyah Miftahul Ulum Kesamben Wetan Driyorejo Gresik, in improving teacher professionalism in the 4.0 revolution era, includes: (1) IT-based training, (2) Education Seminar, (3) Learning workshop in the era of industrial revolution 4.0, (4) ) Education and learning workshops in the digital era, (5) Madrasah supervision carried out by the principal of madrasah ibtidaiyah, (6) Bimtek held by madrasah, (7) Encouraging and motivating teachers to join Teacher Working Groups (KKG), (8) ) Conducting Comparative Studies to higher quality institutions, (9) Conducting social services to around madrassas and communities in need. (10) Workshop with local kyai to strengthen the struggle, (11) Reciting together in collaboration between Madrasah Ibtidaiyah and LP Maarif NU Driyorejo.

Key words: Professionalism, Teachers, Industrial Revolution 4.0.

\section{PENDAHULUAN}

Profesionalisme bagi guru Sekolah Dasar/Madrasah Ibtidaiyah adalah sebuah keniscayaan yang ahrus dimiliki, pemaparan profesionalisme bagi guru terdapat empat kompetensi minimal yaitu pedagogik, professional, social dan kepribadian. Pada dasarnya pembahasan tentang profesionalisme guru sebenarnya sudah teratur sangat jelas pada "Permendiknas Nomor 16 Tahun 2007 tentang Standar Kualifikasi Akademik dan Kompetensi Guru yang menjelaskan bahwa kompetensi profesional yaitu: 1) Menguasai materi, struktur, konsep, dan pola pikir keilmuan yang mendukung mata pelajaran yang diampu. Maka posisi guru harus benarbenar dapat menguasai mata pelajaran yang akan di ajarkan. Keadaan ini juga berlaku pada guru kelas di tingkat dasar yang harus menguasai pelajaran tematik, karena di dalamnya terdapat beberapa bidang keilmuan. 2) Menguasai standar kompetensi dan kompetensi dasar dan mata pelajaran/ bidang pengembangan yang diampu. Setelah menguasai materi, guru kelas mempunyai kewajiban menyederhanakan pembelajaran tematik kepada siswa dengan menyederhanakan capaian yang ditujukkan pada penguasaan guru dalam membuat standart kompetensi dan kompetensi dasar. 3) mengembangkan materi pembelajaran yang diampu secara kreatif wajib dimiliki guru kelas, karena pertemuan antara guru kelas dan siswa yang intens terkadang memberikan kejenuhan bagi siswa 4) Mengembangkan keprofesionalan secara berkelanjutan dengan melakukan tindakan reflektif, pada praktiknya pengembangan professional penting dilakukan guru kelas melalui individu dan kelembagaan 5) memanfaatkan teknologi informasi dan komunikasi untuk berkomunikasi dan mengembangkan diri, Ini menjadi salah satu tantangan guru kelas di era revolusi industri 4.0. guru diharuskan dapat memanfaatkan teknologi sebagai salah satu sumber belajar 
siswa sehingga pembelajaran dapat berjalan secara efektif dan efisien". (Nursalim, 2017)

Era revolusi 4.0 menjadi sebuah era perkembangan teknologi di berbagai lini, di awali dari medi cetak berkembang menjadi basis data besar yaitu media elektronik, tidak tertinggal pada dunia pendidikan yang dahulu terpaku pendidikan berbasis tatap muka, saat ini banyak melakukan transformasi pemanfaatan teknologi berbasis internet sebagai salah satu media pembelajaran guru kelas.(Arif et al., 2020) Maka, disinilah guru mempunyai satu pekerjaan rumah yaitu tentang peningkatan kompetensi di era teknologi.(Mulyana, 2010, p. 9) Tantangan yang dihadapi dunia pendidikan pada era teknologi informasi dan komunikasi semakin kompleks dan bervariasi. Apalagi dalam memasuki era industri 4.0. Mulai dari kurikulum pendidikan, SDM guru, serta ketersediaan sarana dan prasarana, semua patut menjadi perhatian. Oleh karena itu, dalam menghadapi sederet tantangan ini, lembaga pendidikan mesti bersikap lebih dinamis, kreatif, dan inovatif. Jika tidak, lembaga pendidikan akan tergeser arus perkembangan zaman. Masih banyak lembaga yang lambat dalam merespons persoalan didepan mata. Padahal perkembangan masyarakat dan dunia industri terus melesat maju. Lembaga-lembaga masih betah bertahan dengan mindset lama dan berkepikiran dunia dalam keadaan statis (Lafendry, 2019, p. 1).

Peran guru dalam meningkatkan kompetensi di era revolusi 4.0 sudah sepatutnya di manajemen secara maksimal, guru merupakan sumber daya manusia kunci dari pendidikan, maka kualitas sumberdaya yang baik akan diikuti oleh kualitas pendidikan yang baik pula (Supandi et al., 2020) Beberapa pemahaman yang harus di miliki oleh Guru dalam menghadapi era Revolusi Industri 4.0 meliputi 4 prinsip dalam rancangan industri, antara lain: (1) Kesesuaian, adalah sebuah teknik komunikasi dari individu dengan individu lainnya yang di bantu dengan mesin, perangkat dan IOT (2) keterbukaan informasi, adalah sebuah proses keterbukaan yang melibatkan basis data virtual, sehingga dapat di akses secara terbuka tanpa adanya ketertutupan informasi (3) bantuan teknis, adalah bantuan untuk memvisualisasikan keadaan yang terjadi atau dapat di artikan sebagai fisik virtual sebuah pengumpulan data dan (4) keputusan individu. Dengan demikian, manusia dapat mengambil keputusan tanpa adanya diskriminasi dari siapapun. Sehingga mendukung proses pengembangan yang terjadi dalam era revolusi industry 4.0 (Gazali, 2018).

Respon dunia pendidikan terhadap kehadiran Revolusi Industri 4.0 adalah munculnya gagasan Education 4.0 di mana visi pendidikan adalah memotivasi guru dan peserta didik untuk belajar tidak hanya sebatas pengetahuan. Namun, lebih 
pada praktik yang harus di terapakan pada dunia pendidikan. Safiah dalam risetnya menjelaskan secara detail bahwa posisi guru pada pendidikan dasar seharusnya tetap dapat meningkatkan kompetensinya secara maksimal, mulai dari kompetensi pedagogik, profesional, kepribadian sampai sosial, terlebih ketika memasuki era revolusi induastri 4.0. peran berbagai pihak sangat dibutuhkan sehingga seluruh proses pendidikan dapat berjalan dengan baik (Yusrizal et al., 2017) Adanya mengharuskan seorang guru mempunyai skill dan mental yang kuat agar menjadi keunggulan dalam pendidikan, maka dari itu guru harus dapat meningkatkan kompetensi diri. Artinya, tantangan bagi guru adalah harus siap membantu peserta didik dalam mengembangkan kemampuan peserta didik (Retnaningsih, 2019) Selain itu pembahasan tentang respon pendidikan di era revolusi industry 4.0, sangatlah Nampak dengan ditemukannya beberapa hasil penelitian, seperti pada penelitian Lase yang menjelaskan bahwa pentingnya sumber daya manusia dalam lembaga pendidikan sudah tidak dapat di tawar, melihat tantangan yang terjadi, seperti penyesuaian teknologi dengan kemampuan yang di miliki oleh individu guru. Maka, kewajiban guru adalah terus mengembangakan kompetensi yang dimilikinya secara maksimal (Lase, 2019) Priatmoko dalam penelitiannya menjelaskan tentang posisi dunia pendidikan yang harus mengambil peran dalam mengikuti revolusi industry 4.0. mulai dari perbaikan sistem sarana-prasaran, etos kerja, hingga pada pentingnya peningkatan sumberdaya manusia yaitu guru. Karena posisi guru yang tidak dapat tergantikan dalam memberikan pengetahuan awal kepada siswa, selain itu guru diharuskan mampu mencarikan solusi terbaik sehingga siswa dapat belajar dengan nyaman dan maksimal meskipun memasuki era revolusi dengan basis data internet yang lebih dominan(Priatmoko, 2018).

Ghufron dalam penelitiannya mencoba memberikan pandangan yang berimbang antara tantangan dunia pendidikan di era revolusi, seperti pentingnya meningkatkan Sumber Daya Manusia (SDM) pendidik, serta pemahaman terhadap siswa tentang pentingnya memanfaatkan teknologi, maka sudah seharusnya keadaan ini dapat direspon secara cepat dan tepat. Sehingga tantangan tersbut menjadikan peluang bagi dunia pendidikan dalam memberikan pelayanan terbaik kepada siswa (Ghufron, 2018). Sintawati dan Indriani juga memberikan kritik tentang pentingnya sumber daya manusia dalam dunia pendidikan, terutama peran guru dalam memberikan pelajaran pada zaman yang serba digital. Maka, penting bagi guru untuk meningkatkan kompetensi pegadodik melalui TPACK yang bersanding dengan teknologi (Sintawati \& Indriani, 2019). Senada dengan riset di atas Adrian dan Agustina memberikan garis merah tentang pentingnya 
kompetensi guru di era revolusi industry 4.0, karena posisi pendidik harus bisa memaksimalkan dunia teknologi (iptek), sehingga pendidikan dapat berjalan secara maksimal (Adrian \& Agustina, 2019). Muhamad Arif dalam penelitiannya juga menyapaikan tentang pentingnya peningkatan yang dilakukan guru secara individu dalam mengembangkan kompetensi pedagogik dan profesionalnya(Arif, 2018). Berdasarkan beberapa hasil penelitian di atas, terdapat satu bahan diskusi yang di perlukan riset secara mendalam dan spesifik, yaitu tentang strategi sebuah lembaga pendidikan (Madrasah Ibtidaiyah) dalam meningkatkan profesionalisme guru, penelitian ini akan terfokus pada bagaimana peran madrasah ibtidaiyah Miftahul Ulum Kesamben Wetan dalam meningkatkan profesionalisme para guru di era revolusi industri 4.0? Sehingga adanya riset ini dapat memberikan gambaran yang terukur dan strategis pada lembaga pendidikan di era 4.0.

\section{METODE}

Penelitian ini dilakukan pada Madrasah Ibtidaiyah Miftahul Ulum Kesamben Wetan, dengan menggunakan metode kualitatif pendekatan studi kasus yang terdapat pada madrasah ibtidaiyah Miftahul Ulum Kesamben Wetan, keadaan ini diperkuan dengan hasil observasi yang menunjukkan bahwa Madrasah Ibtidaiyah Miftahul Ulum Kesamben Wetan mempunyai strategi khusus dalam meningkatkan profesionalisme guru di era revolusi industri 4.0. Pengambilan data pada sumber data penelitian meliputi seluruh guru kelas mulai dari kelas 1-6 dan kepala madrasah. Sedangkan teknik pengumpulan data menggunakan tiga teknik. Pertama, wawancara tak berstruktur dengan fokus masalah Bagaimana strategi Madrasah Ibtidaiyah Miftahul Ulum Kesamben Wetan dalam meningkatkan profesionalisme guru di era revolusi industri 4.0? dari satu fokus masalah ini terdapat empat bagian. (1) Bagaimana strategi Madrasah Ibtidaiyah Miftahul Ulum Kesamben Wetan meningkatkan kompetensi pedagogik guru di era indusitri 4.0? (2) Bagaimana strategi Madrasah Ibtidaiyah Miftahul Ulum Kesamben Wetan meningkatkan kompetensi profesional guru di era indusitri 4.0?, (3) Bagaimana strategi Madrasah Ibtidaiyah Miftahul Ulum Kesamben Wetan meningkatkan kompetensi kepribadian guru di era indusitri 4.0? (4) Bagaimana strategi Madrasah Ibtidaiyah Miftahul Ulum Kesamben Wetan meningkatkan kompetensi sosial guru di era indusitri 4.0?. Kedua, teknik observasi non partisipatif, yaitu proses partisipasi peneliti kelapangan untuk melakukan observasi yang terfokus pada rumusan masalah. Ketiga, teknik dokumentasi yang relevan, seperti dokumentasi yang berupa foto hasil pelatihan untuk meningkatkan profesionalisme guru di Madrasah Ibtidaiyah Miftahul Ulum Kesamben Wetan. 
Penelitian ini dilakukan pada bulan Mei 2020 hingga November 2020. Pada teknik analisis data yang digunakan peneliti, yaitu teknik analisis data miles and huberman dengan tiga tahapanya, data condensation, data display dan Conclusions Drawing and Verifying.(Miles et al., 2014) Perpadauan uji keabsahan dapa melalui triangulasi dibutuhkan agar dapat memberikan informasi yang valid.

\section{HASIL DAN PEMBAHASAN}

\section{Madrasah dalam Meningkatkan Kompetensi Pedagogik Guru di Era Revolusi Industri 4.0}

Sebagaimana hasil wawancara dan observasi, yang dilakukan peneliti di Madrasah Ibtidaiyah Miftahul Ulum Kesamben Wetan tentang strategi Madrasah dalam meningkatkan kompetensi pedagogik guru di era revolusi industri 4.0, yaitu dengan berbagai jenis strategi, seperti: 1) Pelatihan, penguatan kurikulum 2013 dan pelatihan pembelajaran berbasis IT, 2) Seminar, 3) Workshop, dan 4) Lokarya.

Senada dengan hasil temuan di atas, Kepala Madrasah Ibtidaiyah Miftahul Ulum Kesamben Wetan menjelaskan bahwa dalam meningkatkan kompetensi pedagogik guru di era revolusi industri 4.0, pihak madrasah mengadakan: 1) kegiatan pelatihan, seperti halnya pada saat perubahan kurikulum 2013. 2) Seminar pendidikan di era revolusi industri 4.0, dan 3) Mengadakan workshop dengan trainer dalam bidang teknologi dan inovasi. Selain itu 4) Pihak madrasah juga mengadakan lokarya untuk mendapatkan trobosan-trobosan baru dalam mengelola pembelajaran yang menyenangkan bagi siswa, serta cara mengevaluasi pembelajaran yang efektif. Madrasah ibtidaiyah juga tetap melakukan update pelatihan pembelajaran berbasis teknologi kepada guru, seperti terobosan pembelajaran berbasis google classroom, google form dan zoom meating, mulai dari awal penyampaian pembelajaran hingga tahap evaluasinya.

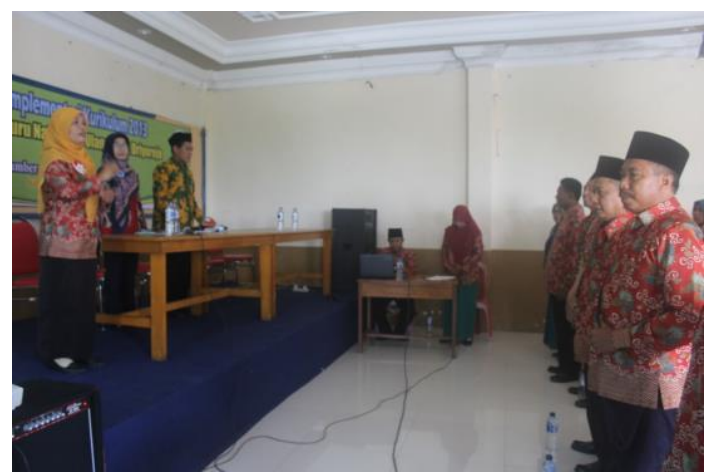

Gambar 1. Pelatihan Pembelajaran Kurikulum 2013

Sumber: Dokumentasi Madrasah Ibtidaiyah Miftahul Ulum 
Pemaparan tersebut juga di sampaikan oleh Guru kelas I A, beliau menyampaikan, tentang Strategi Madrasah Ibtidaiyah Miftahul Ulum dalam meningkatkan kompetensi pedagogik guru di era revolusi industri 4.0. yaitu dengan madrasah mengadakan: 1) Pelatihan pembelajaran berbasis IT mulai dari penguatan RPP, Silabus, yang di adakan oleh pihak madrasah. Selain pelatihan madrasah juga mengadakan 2) Lokarya guna menciptakan animasi pembelajaran pada peserta didik kelas bawah yang berbasis IT. Hal senada juga diungkapkan oleh GK II Unggulan, beliau mengatakan sebagai berikut: Strategi Madrasah Ibtidaiyah Miftahul Ulum dalam meningkatkan kompetensi pedagogik guru di era revolusi industri 4.0 dengan 1) Mengadakan pelatihan pembelajaran berbasis IT, dan pemanfaatanya. Seperti pembelajaran dengan menggunakan LCD namun peserta didik di tunjukkan bagaimana manfaat mesin pencari google. Selain itu madrasah juga 2) Membuat workshop bertemakan pembuatan RPP dan Silabus. Ketika ada pertanyaan kenapa peningkatan itu penting, karena karena peserta didik yang kita hadapi adalah peserta didik generasi milenial yang hampir setiap hari memegang smartphone dan tidak asing lagi dengan dunia digital.

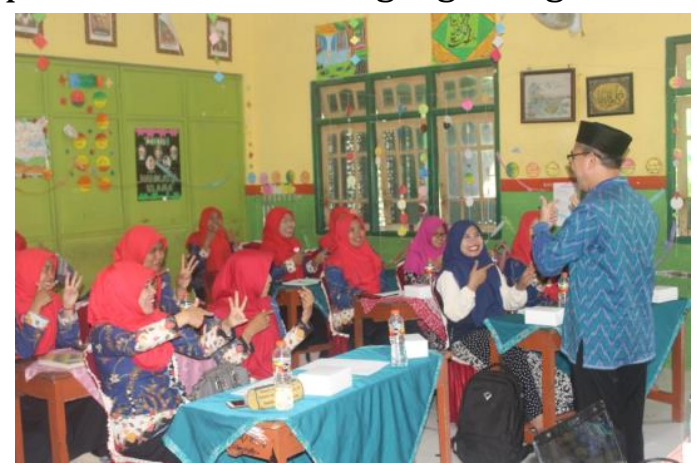

Gambar 2. Workshop Pembelajaran kreatif dan inovativ di era millenial Sumber: Dokumentasi Madrasah Ibtidaiyah Miftahul Ulum

Begitu juga pemaparan dari GK III, tak jauh berbeda jawaban guru lainnya, yaitu: 1) Mengadakan seminar, 2) Mengadakan workshop. Hal tersebut bertujuan untuk menciptakan pembelajaran yang interaktif berbasis IT seperti contoh pembelajaran dengan menggunakan animasi 3D dan sebagainya. Hal senada di sampaikan GK IV, tentang strategi Madrasah Ibtidaiyah Miftahul Ulum dalam meningkatkan kompetensi pedagogik guru di era revolusi industri 4.0 dengan 1) Mengikuti pelatihan yang di adakan oleh madrasah setiap 2-3 bulan sekali bagi guru dengan tujuan mengupdate keilmuan di era revolusi industri 4.0. seperti memaksimalkan pembelajaran dengan penggunaan teknologi informasi, karena dengan perkembangan ICT yang pesat guru profesional harus mampu 
menangkapnya sebagai peluang dan tantangan untuk berkembang lebih baik dalam proses belajar mengajar di madrasah.

Sebagaimana pemaparan para guru tentang Strategi Madrasah Ibtidaiyah Miftahul Ulum dalam meningkatkan kompetensi pedagogik guru di era revolusi industri 4.0 juga di sampaikan oleh GK V, yaitu: 1) Mengikuti pelatihan yang di selenggarakan oleh madrasah dan mandiri, karena ketika kita jadi guru diharuskan terus belajar, karena saat ini semua sudah berbasis teknologi. Contoh saja, saat ini di tengah pendemi covid 19, semua pembelajaran berbasis teknologi, work from home. Jadi kita para guru, selalu di dorong oleh madrasah untuk terus update, selain itu madrasah setiap minggu memberikan pelatihan via zoom meating untuk guru serta penyampaian pembelajaran berbasis IT dan evaluasinya di tengah pandemi covid-19. Senada dengan hasil wawancara di atas, GK VI juga menyampaikan tentang strategi Madrasah Ibtidaiyah Miftahul Ulum dalam meningkatkan kompetensi pedagogik guru di era revolusi industri 4.0 yaitu dengan 1) Mengikuti pelatihan (workshop), 2) Mengikuti seminar yang pernah di adakan oleh madrasah ini. Yang terbaru di sini ketika masa pandemi covid-19 para guru juga tetap melakukan pelatihan, cuman bedanya, semua berbasis teknologi melalui zoom meating. 3) Mengadakan Lokarya.

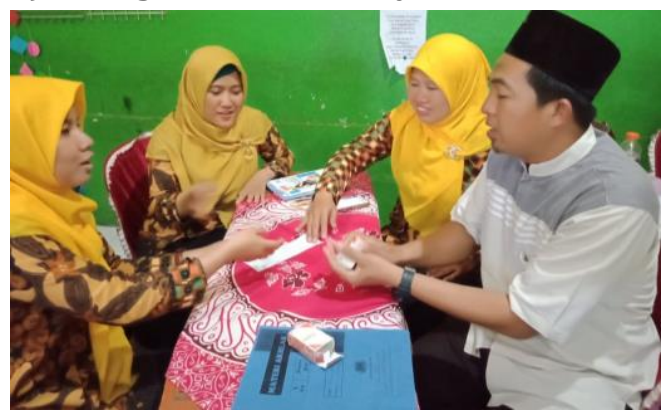

Gambar 3. Lokarya pembelajaran temaik

Sumber: Dokumentasi Madrasah Ibtidaiyah Miftahul Ulum

Berdasarkan hasil penelitian, pembahasan tentang strategi madrasah ibtidaiyah Miftahul Ulum Kesamben Wetan dalam Meningkatkan kompetensi pedagogik di era revolusi industri 4.0. madrasah ibtidaiyah Miftahul Ulum membuat beberapa trobosan yaitu dengan mengadakan, (1) Pelatihan pembelajaran basis IT, mulai dari RPP, Silabus dan literasi media sesuai dengan perkembangan zaman, Senada dengan pemaparan Yohanes dalam bukunya Pelatihan dan Pengembangan SDM Teori dan Praktik yang mejelaskan tentang pentingnya pelatihan terutama bagi guru dalam sebuah lembaga untuk meningkat kompetensinya.(Nugroho, 2019, p. 1) Hal senada juga di sampaikan oleh Happy 
Fitria, Kristiawan dan Rahmat, bahwa pelatihan menjadi salah satu strategi yang tepat dalam meningkatkan kompetensi guru. Karena pelatihan harus di adakan melalui identifikasi kebutuhan, perencanaan, pelaksanaan dan evaluasi berdasarkan kebutuhan guru dan perkembangan dunia.(Fitria et al., 2019) (2) Seminar, menjadi salah satu strategi dalam meningkatkan kompetensi guru, hal ini juga di sampaikan oleh Deitje S. Borang, dengan hasil penelitiannya yang memaparkan bahwa seminar adalah salah satu strategi dalam meningkatkan kompetensi dan profesionalisme guru. Tampaknya hal ini merupakan cara yang paling diminati dan sedang menjadi trend para guru dalam era sertifikasi, karena dapat menjadi sarana untuk mendapatkan angka kredit. Selain itu seminar menjadi, sebuah strategi yang banyak di pilih oleh lembaga dan individu dalam meningkatkan profesinalisme guru.(Borang, 2018) (3) Workshop, pembelajaran di era revolusi industri 4.0, sebagaimana pemaparan dari A.A Ketut Jelatik, dalam bukunya Mengenal Tugas Pokok dan Fungsi Pengawas Sekolah Sebuah Gagasan, Menuju Perbaikan Kualitas Secara Berkelanjutan (Countinous Quality Improvement), yang menjelaskan bahwa kegiatan workshop menjadi sebuah solusi dalam dunia pendidikan. Salah satu dari keunggulan workshop adalah tentang efisiensi waktu dan capaiannya. Karena workshop sudah terjadwal sangat rapi mulai dari awal sampai tujuan (out put).(Jelatik, 2018) Pemapran tersebut juga di sampaikan Sopandi, Wahyu dan Handayani dalam hasil penelitiannya menjelaskan bahwa workshop sangat efektif di gunakan dalam meningkatkan kompetensi, sebagaimana keberadaan workshop juga di lihat dari kebutuhan dan karakteristik guru yang ada di lembaga.(Sopandi et al., 2018) (4) Lokarya pendidikan dan pembelajaran di era digital, seperti menciptakan animasi pembelajaran pada peserta didik berbasis IT. Hal senada juga di sampaikan oleh Subhayni, Sa'adiah, Armia, dalam bukunya yang berjudul Keterampilan Bebicara, menjelaskan bahwa lokarya adalah sebuah program peningkatan kompetensi yang cenderung pada sebuah capaian, di dalamnya sudah terprogram rapi dan menghasilkan produk.(Subhayni et al., 2017) Selain itu hasil penelitian Richardo, menjelaskan bahwa Lokarya penting untuk di adakan pada setiap lembaga pendidikan, dengan adanya lokarya maka para guru dapat diskusi tentang hasil-hasil penelitian yang berkaitan dengan temuan baru yang belum pernah di bahas dan di telitisebelumnya, sehingga menjadi masukan para guru pembelajaran.(Richodo, n.d.) 


\section{Strategi Madrasah dalam Meningkatkan Kompetensi Profesional Guru di Era Revolusi Industri 4.0}

Pemaparan tentang strategi madrasah dalam meningkatkan kompetensi professional disampaikan oleh, Kepala Madrasah ibtidaiyah Miftahul Ulum Kesamben Wetan yaitu dengan 1) senantiasa melakukan kontrol terhadap seluruh aspek pembelajaran dan memberi dampingan pada kesulitan yang dialami tenaga pendidik oleh pihak kepala sekolah dan pengawas madrasah, serta secara bertahap 2) mengadakan pelatihan yang bertujuan memperbaiki kualitas pengelolaan kelas dalam setiap pembelajaran, dan hal ini tidak bisa terlepas dengan Informasi dan teknologi, karena di era ini semua sudah berbeda dengan 10 tahun kemarin. Jadi, kata pihak madrasah harus mengikuti perkembangan yang terjadi. 2) Mengupgrade keilmuan secara mandiri dengan mengikuti forum antar guru, seperti KKG. Sebagaimana pemaparn kepala sekolah, pemaparana dari GK I A, menyampaikan: Bahwa Strategi Madrasah Ibtidaiyah Miftahul Ulum dalam meningkatkan kompetensi profesional guru di era revolusi industri 4.0 adalah: 1) Supervisi dari pihak madrasah yang berkolaboarasi dengan pengawas wilayah driyorejo. 2) Madrasah menyelenggarakan Bimtek untuk para guru.

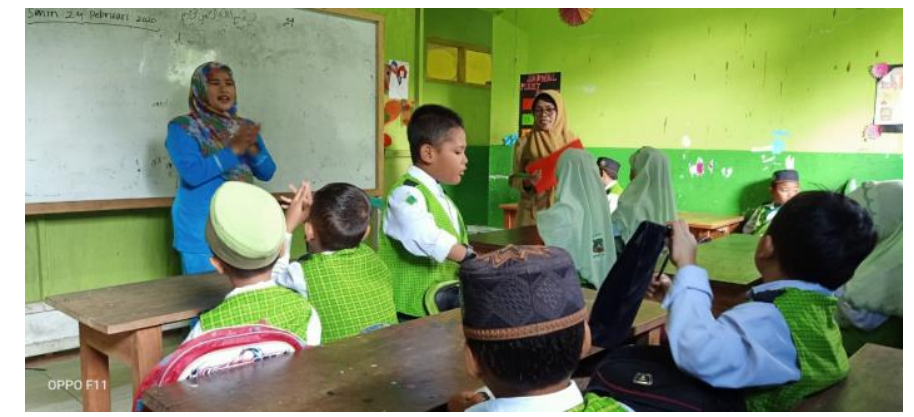

Gambar 4. Supervisi Madrasah

Sumber: Dokumentasi Madrasah Ibtidaiyah Miftahul Ulum

Hal senada disampaikan oleh GK II Unggulan, beliau mengatakan: Strategi Madrasah Ibtidaiyah Miftahul Ulum dalam meningkatkan kompetensi profesional guru di era revolusi industri 4.0 dengan 1) Megikuti pelatihan yang di adakan oleh madrasah, 2) seminar 3) Bimbingan teknis tentang pengelolaan kelas, dan 4) Diskusi antar guru (KKG). Senada dengan pemaparan di atas, GK III C juga menyampaikan terkait strategi madrasah dalam meningkatkan kompetensi profesional yaitu: Strategi Madrasah Ibtidaiyah Miftahul Ulum dalam meningkatkan kompetensi profesional guru di era revolusi industri 4.0 dengan 1) Adanya supervisi dari pihak madrasah 2) pelatihan khusus para pendidik yang di adakan oleh madrasah baik secara offline dan online. Serta, di adakanya 3) 
workshop dari pihak madrasah, dengan tujuan menambah wawasan baru di era revolusi industri 4.0. bagi guru. Strategi madrasah dalam meningkatkan kompetensi profesional juga disampaikan GK IV , beliau mengatakan bahwa Strategi Madrasah Ibtidaiyah Miftahul Ulum dalam meningkatkan kompetensi profesional guru di era revolusi industri 4.0 meliputi: 1) Mengadakan pelatihan bagi guru terutama dalam upaya peningkatan kompetensi profesional, dan 2) Workshop, tentang penguatan dalam pengelolaan kelas, yang di adakan oleh pihak madrasah.

Sebagaimana pemaparan sebelumnya tentang Strategi Madrasah Ibtidaiyah Miftahul Ulum dalam meningkatkan kompetensi profesional guru di era revolusi industri 4.0 juga di sampaikan oleh GK V, beliau mengatakan bahwa: 1) Madrasah mengadakan pelatihan bagi seluruh guru dan 2) Seminar. Hal senada juga di sampaikan oleh GK VI , beliau mengatakan: Strategi Madrasah Ibtidaiyah Miftahul Ulum dalam meningkatkan kompetensi profesional guru di era revolusi industri 4.0 dengan 1) Supevisi pendidikan yang di adakan oleh madrasah setiap 3 bulan sekali, selain itu madrasah mengadakan pelatihan, 2) dorongan dari kepala madrasah untuk mengikuti KKG tingkat kecamatan Driyorejo. Pada dasarnya seluruh strategi di atas adalah untuk meningkatkan kompetensi profesional seorang guru.

Dari hasil beberapa hasil di atas dapat dilakukan pembahasan yaitu tentang, strategi madrasah ibtidaiyah Miftahul Ulum Kesamben Wetan dalam meningkatkan kompetensi Profesional, meliputi: (1) Supervisi Madrasah yang dilakukan oleh kepala madrasah ibtidaiyah, hal tersebut di kuatkan oleh hasil penelitian Henny Indrawati menjelaskan bahwa Supervisi dilakukan dengan tujuan untuk melakukan perbaikan secara berkelanjutan yang nantinya akan dijadikan bahan evaluasi untuk meningkatkan kompetensi guru dalam pembelajaran.(Arif \& Sulistianah, 2019) Karena dengan supervisi kepala sekolah bisa membantu guru dalam memecahkan persoalan yang dihadapi.(Indrawati, 2016) Hal senada di sampaikan Tamrin, bahwa penerapan supervisi dalam mengevaluasi kinerja pendidik sangatlah tepat.(Tamrin, 2021) (2) Bimtek yang di adakan oleh madrasah, sebagaimana penjelasan Muhamad Arif tentang pentingnya Bimtek era revolusi industri 4.0, melihat pendidikan berkembang begitu pesat seiring dengan kemajuan teknologi informasi. Maka guru tidak lagi terbatas untuk mendapatkan informasi kapan dan di mana akan diadakan kegiatan tersebut. Guru dapat memilih kegiatan yang sesuai dengan kebutuhannya yang dapat di ikuti dalam rangka meningkatkan kompetensi dan mendukung jenjang karir.(Arif, 2018) 
Hal senda juga di sampaikan Ranti Safiah, tentang keberadaan Bimtek sebagai upaya lembaga dalam mengembangkan mutu seorang guru dan tenaga pendidik, karena dengan mengikuti bimtek, secara otomatias para pendidik akan mengikuti perkembangan dalam dunia pendidikan.(Safi'ah, 2017) (3) Mendorong dan memotivasi para guru untuk mengikuti Kelompok Kerja Guru (KKG). Sebagaimana hasil penelitian Wayan Resmini, tentang Pembinaan Kemampuan Profesional Guru Melalui Kelompok Kerja Guru (KKG), menjelaskan tentang tujuan untuk mengawal profesionalisme seorang guru meliputi kompetensi pedagogik, profesional, kepribadian dan sosial didalamnya terbingkai tentang bagaimana guru merencanakan pembelajaran, melaksanakan dan mengevaluasi pembelajaran.(Resmini, 2010) (4) Mengadakan Pelatihan juga menjadi catatan lembaga agar secara continue memberikan pelatihan kepada guru, sehingga guru tetap dapat meningkatkan kompetensi yang dimiliknya, selain itu, diharapkan guru dapat membeikan pelayanan terbaik kepada siswa dalam proses pembelajaran.(Myori et al., 2019) (5) Seminar, dan (6) Mengadakan workshop pembelajaran sebagai upaya madrasah dalam mengikuti perkembangan pendidikan serta memperbaiki mutu pendidikan.(Safi'ah, 2017)

\section{Strategi Madrasah dalam Meningkatkan Kompetensi Sosial Guru di Era Revolusi Industri 4.0}

Strategi Madrasah ibtidaiyah Miftahul Ulum dalam meningkatkan kompetensi sosial guru di era revolusi industri 4.0. dengan menggunakan beberapa strategi yaitu: 1) Studi banding kepada madrasah ibtidaiyah yang lebih maju dan bermutu. 2) Mengajak para guru untuk mengikuti Bakti sosial di lingkungan madrash ibtidaiyah. Hal tersebut di kuatkan oleh hasil waancara kepada KM, tetang strategi madrasah dalam meningkatkan kompetensi sosial di era revolusi industri 4.0 adalah dengan 1) mengajak para guru studi banding di madrasah bonafit, agar para guru dapat belajar dari madrasah tersebut. memberikan contoh dan praktik secara langsung, 2) Mengajak seluruh elemen madrasah untuk ikut serta dalam melaksanakan bakti sosial kepada masyarakat madrasah dan sekitarnya. Seperti contoh, setiap datang bulan ramadhan kita mempunyai mewajibkan guru untuk zakat dan membantu menyalurkannya. Sebagaimana pemparan KS, juga diungkapkan oleh GK I A, menyatakan beberapa Strategi madrasah dalam meningkatkan kompetensi sosial di era revolusi industri 4.0 yaitu dengan: 1) madrasah mengajak para guru untu studi banding ke pesantren yang di dalamnya mempunyai lembaga pendidikan dan bermutu dalam pengelolaanya, selain studi banding, 2) Para guru di ajak untuk ikut serta dalam bakti sosial yang di agendakan oleh madrasah. Senada dengan pemaparan di atas, 
hasil wawancara kepada GK II Unggulan, juga menyampaikan demikian bahwa madrasah ikut sumbangsih dalam meningkatkan kompetensi sosial guru, yaitu:1) Mengadakan studi banding kepada madrasah sekitar terutama madrasah yang ada didalam lingkungan pondok pesantren. 2) Selain itu pihak madrasah mengadakan kegiatan bakti sosial kepada masyarakat sekitar madrasah".

Sedangkan GK III C, juga menyampaikan tentang strategi madrasah dalam meningkatkan kompetensi sosial di era revolusi industri 4.0. yaitu dengan mengikuti kegiatan yang di buat madrasah, 1) Studi Banding 2) mengajak para elemen madrasah untuk meningkatkan kepekaan sosial keada mereka yang membutuhkan, yaitu melakukan bakti sosial kepada msyarakat sekitar. Senada dengan pemaparan di atas, GK IV, menyampaikan tentang, beberapa Strategi madrasah ibtidaiyah Miftahul Ulum Kesamben Wetan dalam meningkatkan kompetensi sosial di era revolusi industri 4.0 adalah: 1) Pihak madrasah mengadakan studi banding ke pondok pesantren yang di dalamnya terdapat madrasah ibtidaiyah. 2) Selain itu para guru di motivasi kepala madrasah dengan meningkatkan kompetensi secara individu, seperti mengikuti perkembangan dunia melalui you tube dan media sosial lainnya". Hal senada disampaikan oleh GK V, tentang beberapa strategi madrasah dalam meningkatkan kompetensi sosial di era revolusi industri 4.0 yaitu: 1) Mengagendakan studi banding ke pondok pesantren yang mempunyai lembaga pendidikan setiap 1 tahun sekali 2) mengjak elemen madrasah untuk ikut serta dalam bakti sosial yang di adakan madrasah. Sebagaiman pemaparan di atas, GK VI, juga menyampaikan, tentang strategi madrasah dalam meningkatkan kompetensi sosial di era revolusi industri 4.0 adalah dengan 1) Memfasilitasi para guru untuk melakukan diskusi antar guru kelas, dan 2) mengajak guru untuk studi banding ke lembaga yang lebih berkualitas dan bermutu.

Sejalan dengan strategi madrasah ibtidaiyah Miftahul Ulum Kesamben Wetan dalam meningkatkan kompetensi profesional. Beberapa strategi madrasah ibtidaiyah Miftahul Ulum Kesamben Wetan dalam meningkatkan kompetensi sosial adalah meliputi: (1) Mengadakan Studi Banding kepada lembaga yang lebih bermutu, hal ini juga di sampaikan Imam Rochayadi, dari hasil penelitian yang berjudul Upaya Meningkatkan Kompetensi Guru Paud Melalui Pendidikan dan Pelatihan Guru di PAUD Bougenville Kecamatan Sukjadi Kota Bandung, menjelaskan bahwa Studi banding di perlukan kepada para pemangku lembaga guna mengukur dan mengembangkan lembaganya lebih-lebih pada era digital.(Rochayadi, 2014) Hal tersebut juga disampaikan Safi'ah, bahwa peran studi banding sangatlah efektif dalam upaya mengembangakan mutu seluruh pendidik 
di sebuah lembaga pendidikan. Karena dengan melakukan studi banding kepada sekolah yang lebih bermutu, diharapkan nantinya para guru dan kepala madrasah dapat mengambil contoh untuk diberlakukan pada lembaganya.(Safi'ah, 2017) (2) Mengadakan bakti sosial kepada sekitar madrasah dan masyarkat yang membutuhkan. Bakti social menjadi sebuah keharusan dalam memberikan empati kepada masyarakat sekitar, terutama bagi meraka yang membutuhkan. Hal tersebut akan membangun serta meningkatkan karakter yang ada pada diri guru, sehingga nantinya dapat di salurkan kepada siswa.(Natsir, 2007)

\section{Strategi Madrasah dalam Meningkatkan Kompetensi Kepribadian Guru di Era Revolusi Industri 4.0}

Strategi madrasah dalam meningkatkan kompetensi kepribadian guru di era revolusi industri 4.0, meliputi: 1) Pelatihan 2) sarasehan dengan para kyai sekitar, 3) Ngaji bareng kyai hasil kerjasama antara madrasah ibtidaiyah dan LP Ma'arif NU Driyorejo, yang di adakan setiap hari sabtu pahing. Hal tersebut juga di kuatkan oleh hasil wawancara kepada Kepala Madrasah Ibtidaiyah Miftahul Ulum Kesamben Wetan tentang strategi madrasah dalam meningkatkan kompetensi kepribadian guru di era revolusi industri 4.0. adalah dengan 1) Mengadakan sarasehan bersama kyai sekitar yang di dalamnya membahas tentang kitab-kitab pesantren terutama bab adab dalam menuntut ilmu bagi guru dan murid. 2) Menjalin kerjasama dalam kegiatan Ngaji bareng setiap satu bulan sekali bertepatan pada hari sabtu pahing yang bekerjasama dengan lembaga ma'arif $\mathrm{NU}$ driyorejo. Kajian kitab kuning, seperti kitab pendiri organisasi Nahdlatul Ulama' yaitu KH. Hasyim Asy'ari yang berjudul Adabul Alim Wal Muta'alim, sebuah kitab yang membahas tentang adab seorang guru dan murid. Hal ini penting dan wajib bagi guru mempelajarinya, karena di era saat ini, kita didorong untuk mengikuti perkembangan zaman. Namun, agar tidak lalai dalam hal akhlak (adab) dan guru wajib memberikan teladan kepada siswa".

Sejalan dengan pemaparan di atas, GK I juga menyampaikan demikian tentang Strategi madrasah dalam meningkatkan kompetensi kepribadian di era revolusi industri 4.0. dengan mengadakan sarasehan yang mengundang kyai sekitar, seperti madrasah mengundang KH. Mulyadi, MM, sebagai pemateri dalam dalam sarasehan denga para guru dan staff di madrasah ini, dan 2) setiap hari Sabtu Pahing, madrasah mengajak untuk ngaji bareng di Mwcnu Driyorejo, semunya dilakukan tidak lain sebagai penguat kepribadian guru, karena guru sebagai teladan yang di ikuti oleh siswa". Hal tersebut juga di sampaikan oleh GK II, tentang strategi madrasah dalam meningkatkan kompetensi kepribadian guru di era revolusi industri 4.0. yaitu dengan 1) Melakukan kajian-kajian keislaman dan 
kerohanian, dengan konsep ngaji bareng bersama para kyai di bawah naungan organisasi Nahdlatul Ulama' yang di dalamnya membahas kajian Kitab Mbah Hasyim tentang pentingnya akhlak bagi seorang guru dan murid. 2) mengadakan sarasehan dengan kyai sekitar dalam penguatan kepribadian yang berakhlak. Senada dengan GK II Unggulan, GK III C, juga menyampaikan hal serupa, bahwa strategi madrasah dalam meningkatkan kompetensi kepribadian guru di era revolusi industri 4.0. adalah dengan mengadakan kajian kerohanian, seperti sarasehan bersama kyai yang di dalamnya membahas tentang pentingnya menguatkan pribadi seorang guru (seperti guru yang berakhlak, berkepribadian yang arif kepada siswa dan wali siswa. Sedangkan pemaparan senada juga di sampikan GK IV, tentang bagaimana stategi madrasah dalam meningkatkan kompetensi kepribadian guru di era revolusi industri 4.0. adalah dengan 1) Mewajibkan bagi guru untuk mengikuti ngaji bareng bersama para kyai, acara hasil kerjasama antara lembaga ma'arif dan madrasah ibtidaiyah. dan 2) Pihak madrasah setiap 3 bulan sekali mengundang kyai sekitar untuk memberikan penguatan perjuangan kepada para guru, yang di bingkai dengan sarasehan. Meskipun perkembangan di era digital luar biasa, tapi kita para guru tetap wajib menjaga kepribadian yang bijaksana sehingga para siswa dapat menirunya.

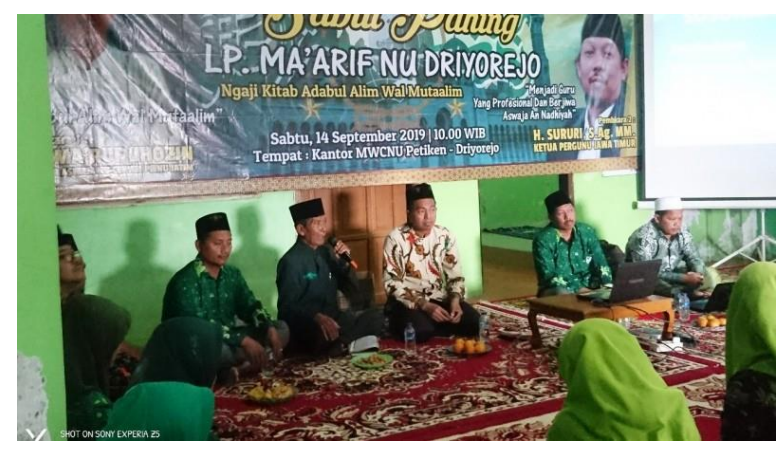

Gambar: 4. Ngaji Bareng Sabtu Pahing

Sumber: Dokumentasi LP Ma'arif NU Driyorejo

Sebagaimana pemaparan informan sebelumnya, pemaparan senada juga di sampaikan oleh GK V, tentang strategi madrasah dalam meningkatkan kompetensi kepribadian guru di era revolusi industri 4.0. adalah dengan 1) pihak madrasah mengadakan sarasehan bersama kyai dan 2) mendorong guru untuk mengikuti ngaji bareng setiap sabtu pahing yang di adakan hasil kerjasama antara madrasah dan LP Ma'arif Driyorejo. Sebagaimana pemaparan di atas GK VI, juga menyampaikan tentang beberapa strategi madrasah dalam meningkatkan kompetensi kepribadian, yaitu: 1) Mengajak seluruh elemen madrasah, yaitu para 
guru dan staff untuk mengikuti ngaji bareng bersama para masyayikh, yang pada dasarnya adalah menguatkan kepribadian seorang guru. Karena dalam kajiannya para kyai lebih menyoroti tentang kepribadian seperti adab, kebijaksanaan dan kedermawanan. Selain ngaji bareng, 2) Madrasah itidaiyah Miftahul Ulum juga mengadakan sarasehan bersama kyai sekitar. Selain beberapa strategi Madrasah Ibtidaiyah Miftahul Ulum Kesamben Wetan Driyorejo Gresik dalam meningkatkan profesionalisme guru di era revolusi 4.0 di atas, masih ditemukan beberapa kendala dalam meningkatkan profesionalisme guru diantaranya terbatasnya unit komputer (leptop), sering terjadinya trouble pada jaringan wifi madrasah.

Sedangkan strategi madrasah ibtidaiyah Miftahul Ulum Kesamben Wetan dalam meningkatkan kompetensi kepribadian meliputi: (1) Sarasehan bersama kyai sekitar untuk menguatkan perjuangan dalam mengamalkan ilmu sebagaimana yang disampaikan oleh Subhayni, Sa'adiah, dan Armia dalam bukunya keterampilan berbicara menjelaskan bahwa sarasehan merupakan salah satu cara dalam meningkatkan kompetensi guru. Karena sarasehan lebih pada mengungkapkan kesulitan ataupun terobosan dari berbagai permasalahan yang dialami guru.(Subhayni et al., 2017) Hal senada juga di sampaikanpada hasil penelitian Nur Ahid, yang menjelaskan bahwa peran sarasehan sebagai bentuk kursus yang non formal sangatlah tepat untuk diterapkan dalam dunia pendidikan, karena dengan sarasehan cenderung mendapatkan temuan-temuan baru dalam pendidikan.(Ahid, 2006) (2) Ngaji bareng kyai adalah sebuah trobosan kerja sama antara madrasah ibtidaiyah Miftahul Ulum Kesamben Wetan dengan LP Ma'arif NU Driyorejo yang bertujuan menguatkan pentingnya adab (akhlak) bagi guru dan murid dengan mengkaji kitab KH Hasyim Asy'ari yang berjudul Adabul Alim Wal Muta'alim.

\section{SIMPULAN}

Berdasarkan fokus masalah penelitian yaitu, bagaimana strategi madrasah ibtidaiyah Miftahul Ulum Kesamben Wetan Driyorejo Gresik dalam meningkatkan profesionalime guru di era revolusi industri 4.0, mendapatkan hasil sebagai berikut: Strategi madrasah ibtidaiyah Miftahul Ulum Kesamben Wetan Driyorejo Gresik, dalam meningkatkan profesionalisme guru di era revolusi 4.0 meliputi: (1) Pelatihan berbasis IT, (2) Seminar Pendidikan, (3) Workshop pembelajaran di era revolusi industri 4.0, (4) Lokarya pendidikan dan pembelajaran di era digital, (5) Supervisi Madrasah yang dilakukan oleh kepala madrasah ibtidaiyah, (6) Bimtek yang di adakan oleh madrasah, (7) Mendorong dan memotivasi para guru untuk mengikuti Kelompok Kerja Guru (KKG), (8) Mengadakan Studi Banding kepada 
lembaga yang lebih bermutu, (9) Mengadakan bakti sosial kepada sekitar madrasah dan masyarkat yang membutuhkan. (10) Sarasehan bersama kyai sekitar untuk menguatkan perjuangan, (11) Ngaji Bareng kerja sama antara Madrasah Ibtidaiyah dan LP Maarif NU Driyorejo.Dari beberapa strategi Madrasah Ibtidaiyah Miftahul Ulum Kesamben Wetan Driyorejo Gresik dalam meningkatkan profesionalisme guru di era revolusi 4.0 di atas, masih ditemukan beberapa kendala dalam meningkatkan profesionalisme guru diantaranya terbatasnya unit komputer (leptop) dan sering terjadinya trouble pada jaringan wifi madrasah.

\section{DAFTAR RUJUKAN}

Adrian, Y., \& Agustina, R. L. (2019). Kompetensi Guru di Era Revolusi Industri 4. Lentera: Jurnal Pendidikan, 14(2), 175-181. https://doi.org/10.33654/jpl.v14i2.907

Ahid, N. (2006). Konsep dan Teori Kurikulum dalam Dunia Pendidikan. Islamica, 1(1), 14-29.

Arif, M. (2018). Peningkatan Kompetensi Pedagogik Dan Profesional Guru Kelas Madrasah Ibtidaiyah Di Kabupaten Gresik (Studi Multi Kasus di Madrasah Ibtidaiyah Plus Riyadlatul Athfal Hulaan Menganti dan Madrasah Ibtidaiyah Mamba'us Sholihin Suci Manyar). UIN Sunan Ampel Surabaya.

Arif, M., Mulyadi, M., Bahrozi, I., \& Hudah, N. (2020). Madrasah Ibtidaiyah Transformation Based on Pesantren in the Era of Industrial Revolution 4.0. Psychology And Education, 57(8), 420-435.

Arif, M., \& Sulistianah, S. (2019). Problems in 2013 Curriculum Implementation for Classroom Teachers in Madrasah Ibtidaiyah. Al Ibtida: Jurnal Pendidikan Guru MI, 6(1), 110. https://doi.org/10.24235/al.ibtida.snj.v6i1.3916

Borang, D. S. (2018). Upaya Peningkatan Kompetensi dan Profesionalisme Guru SMK Di era Sertifikasi. Seminar Internasional Peran LPTK Dalam Pengembangan Pendidikan Vokasi Di Indonesia.

Fitria, H., Kristiawan, M., \& Rahmat, N. (2019). Upaya Meningkatkan Kompetensi Guru Melalui Pelatihan Penelitian Tindakan Kelas. Abdimas Unwahas, 4(1), 14-25.

Gazali, E. (2018). Pesantren Di Antara Generasi Alfa Dan Tantangan Dunia Pendidikan Era Revolusi Industri 4.0.2(2), 16.

Ghufron, M. A. (2018). Revolusi Industri 4.0: Tantangan, Peluang Dan Solusi Bagi Dunia Pendidikan. Seminar Nasional dan Diskusi Panel Multidisiplin Hasil Penelitian \& Pengabdian kepada Masyarakat, 6. 
Indrawati, H. (2016). Upaya Peningkatan Kompetensi Profesional Guru Mata Pelajaran Ekonomi dalam Proses Pembelajaran. Pendidikan Ekonomi FKIP Universitas Riau Pekanbaru, 12(1), 92-100.

Jelatik, A. A. K. (2018). Mengenal Tugas Pokok dan Fungsi Pengawas Sekolah Sebuah Gagasan, Menuju Perbaikan Kualitas Secara Berkelanjutan (Countinous Quality Improvement). Budi Utama.

Lafendry, F. (2019). Guru Kreatif dan Menyenangkan Pada Era Millenial. Salemba Humanika.

Lase, D. (2019). Pendidikan di Era Revolusi Industri 4.0. SUNDERMANN: Jurnal Ilmiah Teologi, Pendidikan, Sains, Humaniora dan Kebudayaan, 12(2), 28-43. https://doi.org/10.36588/sundermann.v1i1.18

Miles, Mattew. B., Hubarman, A. M., \& Saldana, J. (2014). Qualitative Data Analiysis A Metode Sourcebook Edition 3. Sage.

Mulyana, M. (2010). Rahasia Guru Hebat. PT. Gramedia Widiasarana.

Myori, D. E., Hidayat, R., Eliza, F., \& Fadli, R. (2019). Peningkatan Kompetensi Guru dalam Penguasaan Teknologi Informasi dan Komunikasi melalui Pelatihan Pengembangan Media Pembelajaran Berbasis Android. JTEV: Jurnal Teknik Elktro dan Vokasional, 5(2), 102-109.

Natsir, N. F. (2007). Peningkatan Kualitas Guru dalam Perspektif Pendidikan Islam. 1(11), 20-27.

Nugroho, Y. R. B. (2019). Pelatihan dan Pengembangan SDM Teori dan Praktik. Universitas Katolik Indonesia Atma Jaya.

Nursalim, N. (2017). Profesionalisme Guru SD/ MI. Lentera Pendidikan, 20(2), 240252.

Priatmoko, S. (2018). Memperkuat Eksistensi Pendidikan Islam Di Era 4.0. Ta'lim: Jurnal Studi Pedidian Islam, 1(2), 221-239.

Resmini, W. (2010). Pembinaan Kemampuan Profesional Guru Melalui Kelompok Kerja Guru (KKG). Ganec Swara, 4(1), 59-62.

Retnaningsih, D. (2019). Tantangan dan Strategi Guru di Era Revolusi Industri 4.0 dalam Meningkatkan Kualitas Pendidikan. Prosiding Seminar Nasional: Kebijakan Dan Pengembangan Pendidikan Di Era Revolusi Industri 4.0.

Richodo, R. (n.d.). Program Guru Pembeljaran: Upaya Meningkatkan Profesionalisme Guru Abad 21. Prosiding Seminar Matematika Dan Pendidikan Matematika, November 2016.

Rochayadi, I. (2014). Upaya Meningkatkan Kompetensi Guru Paud Melalui Pendidikan dan Pelatihan Guru di PAUD Bougenville Kecamatan Sukjadi Kota Bandung. Jurnal Empowerment, 4(1), 1-10. 
Bela Vita Rismawati, Muhamad Arif, Muhammad Mahfud

Safi'ah, R. (2017). Upaya PengembanganMadrasah Ibtidaiyah Ma'arif Bego Tahun Ajaran 2014-2015. Jurnal Pendidikan Madrasah, 2(2), 235-250.

Sintawati, M., \& Indriani, F. (2019). Pentingnya Technological Pedagogical Content Knowledge (tpack) Guru Di Era Revolusi Industri 4.0.6.

Sopandi, W., Pratama, Y. A., \& Handayani, H. (2018). Sosialisasi dan Workshop Implementasi Model RADEC Bagi Guru-Guru Pendidikan Dasar dan Menengah. Pedagogia: Jurnal Pendidikan, 8(1), 19-34.

Subhayni, S., Sa'diah, S., \& Armia, A. (2017). Keterampilan Berbicara. Syiah Kaula Universit Press.

Supandi, A., Sahrazad, S., Wibowo, A. N., \& Widiyarto, S. (2020). Analisis Kompetensi Guru: Pembelajaran Revolusi Industri 4.0. Prosiding Samasta:Seminar Nasional Bahasa dan Sastra Indonesia, 6.

Tamrin, T. (2021). Peningkatan Kemampuan Mengajar Berbasis Keterampilan Abad 21 Melalui Supervisi Akademik Metode Pemodelan Teman Sejawat Bagi Guru SD Gugus I Kecamatan Rappocini Kota Makassar. JIKAP PGSD: Jurnal Ilmiah Ilmu Kependidikan, 5(1), 105-111.

Yusrizal, Y., Safiah, I., \& Nurhaidah, N. (2017). Kompetensi Guru Dalam Memanfaatkan Media Pembelajaran Berbasis Teknologi Informasi Dan Komunikasi (tik) Di Sd Negeri 16 Banda Aceh. 2(2), 126-134. 